\title{
THE RECYCLED OROGENIC SAND PROVENANCE FROM AN UPLIFTED THRUST BELT, BETIC CORDILLERA, SOUTHERN SPAIN
}

\author{
SALVATORE CRITELLI ${ }^{1}$, JOSÉ ARRIBAS ${ }^{2}$, EMILIA LE PERA ${ }^{3}$, AMPARO TORTOSA $^{2}$, KATHLEEN M. MARSAGLIA $^{4}$, AND \\ KELLY K. LATTER ${ }^{5}$ \\ ${ }^{1}$ Dipartimento di Scienze della Terra, Università degli Studi della Calabria, I-87036 Arcavacata di Rende (CS), Italy \\ ${ }^{2}$ Departamento de Petrologia y Geoquimica, Facultad de Ciencias Geologicas, Universidad Complutense de Madrid, Madrid, Spain \\ ${ }^{3}$ Consiglio Nazionale delle Ricerche-Istituto di Ricerca per la Protezione Idrogeologica nell'Italia Meridionale ed Insulare, Via Cavour, \\ 87030 Roges di Rende (CS), Italy \\ ${ }^{4}$ Department of Geological Sciences, California State University, Northridge, California 91330-8266, U.S.A. \\ ${ }^{5}$ Department of Geological and Environmental Sciences, University of Texas at El Paso, El Paso, Texas 79968, U.S.A. \\ e-mail: critelli@unical.it
}

Abstract: The Betic Cordillera of southern Spain represents an uplifted foreland fold-thrust belt. Source rock types of the Betic Cordillera include metamorphic (mainly phyllite, schist, quartzite, and gneiss), sedimentary (siliciclastic and carbonate), volcanic (felsic to intermediate pyroclasts), and mantle-derived (peridotite, gabbro, serpentinite, and serpentine schist) rocks. The fluvial systems range that transect the Betic Cordillera are the major detrital source of sediment along the southern Spanish coast, supplying sand to beaches and offshore depositional systems in the Alboran Sea basin.

Three key sand petrofacies derived from the Betic mountain belt reflect the main clastic contribution of known source rocks. All the sands are quartzolithic, ranging from quartz-rich to lithic-rich.

Fluvial systems draining the Sierra de Los Filabres, the Sierra Nevada, the Sierra de Gador, and the Málaga Mountains, and their related beaches constitute a metamorphic-sedimenticlastic quartzolithic sand petrofacies $(\mathrm{Qm} 34 \pm 10 \mathrm{~F} 4 \pm 3 \mathrm{Lt} 62 \pm 9 ; \mathrm{Lm} 72 \pm 14 \mathrm{Lv} 2 \pm 4$ Ls26 \pm 13 ), derived dominantly from the Nevado-Filábride, Alpujárride, and Maláguide complexes. This quartzolithic petrofacies extends from northeast of Almeria to Torremolinos (southwest of Málaga), and northeast of Algeciras. Only one beach sand sample, east of Cabo de Gata, is volcanolithic. Volcanic detritus (mainly having felsitic textures) is derived from Miocene (15-7 Ma) pyroclastic sequences cropping out in the southeast of the chain.

This metamorphic-sedimenticlastic quartzolithic petrofacies changes in the coastal stretch from Torremolinos to Marbella, where drainage systems cut across the Serrania de Ronda. Here source rock types include peridotite, gabbro, and serpentinite of the Ronda Peridotite Massif, and metamorphic rocks of the Málaguide and Alpujárride units. The fluvial and beach sands of this area are quartzolithic $(Q m 32 \pm 12$ F10 \pm 3 Lt58 \pm 11$)$, and include abundant peridotite and serpentinite grains. The latter quartzolithic petrofacies changes abruptly from Algeciras to Cádiz, where the sand becomes quartz-rich $(\mathrm{Qm} 77 \pm 5 \mathrm{~F} 4 \pm 2 \mathrm{Lt19} \pm 4)$. This sand petrofacies is derived predominantly from recycling of sedimentary sequences, mainly the quartzarenite turbidite units of the Gibraltar Arc (the Algeciras Flysch). This petrofacies is characterized by higher proportion of quartz grains and abundant sedimentary lithic fragments $(\mathrm{Lm} 1 \pm 3 \mathrm{Lv} 1 \pm 1 \mathrm{Ls} 98 \pm 3)$.

The three onshore petrofacies plot in the recycled-orogen provenance compositional field and the lithic to transitional to quartzose recycled subfields of Dickinson (1985). They vary from lithic, to transitional and quartzose depending on their source lithologies in the Betic foreland fold-thrust belt. These actualistic petrofacies best describe the nature and distribution of sand petrofacies derived from a collisional fold-thrust belt where primary and recycled source rocks are interfingered.

Deep-marine turbidites of the Alboran Basin have basinwide quartzolithic sands having close compositional relations with Betic Cordillera onshore sand petrofacies. Comparison of detrital modes from mainland to deep-marine environments provides a suitable basis for interpreting the Miocene to Pleistocene sand dispersal history in the Alboran Basin. These modern quartzolithic petrofacies are used to interpret analogous ancient collisional sandstone petrofacies of the Alpine orogenic belt of the western-central Mediterranean region and of other collisional orogenic systems, as a broader point of view.

\section{INTRODUCTION}

The Betic Cordillera is an uplifted thrust belt, consisting of several thrust units and having a wide spectrum of source rock types, including metamorphic (low- to high-grade), mantle-exhumed rocks (peridotite complex), sedimentary (carbonate, siliciclastic, and evaporite), and volcanic rocks. These source rocks supply large amounts of detritus to the coastal and marine environments of the Alboran Sea.

The Alboran Sea is a tectonically active, postcollisional basin, located in the broad region of deformation that marks the modern African and European plate boundary. This extensional basin is superimposed on the Alpine orogenic belt, and it is surrounded by the Betic and Rif mountain belts (Fig. 1).

The Alboran Basin has been intensely investigated, most recently by the Ocean Drilling Program (ODP) on Leg 161 (Zahn et al. 1999). One purpose of ODP Leg 161 was to characterize and compare the depositional history of the Alboran and other sub-basins of the Western Mediterranean (Comas et al. 1996). Marsaglia et al. (1999) used samples from the Leg 161 cores to investigate the history of Miocene to Pleistocene detrital sedimentation in the Alboran Basin. One of their main conclusions was that the turbidite sands at Sites 976, 977, and 978 were derived from the Betic Cordillera of southern Spain.

The Betic Cordillera and the Alboran Basin represent a well known orogenic system of a collisional chain and the associate extensional basin, respectively. Actualistic studies on modern petrofacies in this area allows interpreting geotectonic provenance in analogous geologic settings. To better characterize the onshore dispersal pathways and the geographical distributions of modern sand petrofacies around the northern active flank of the Alboran Sea, we determined the detrital modes of sand samples from fluvial and beach environments of the Mediterranean and Atlantic sides of the Betic Cordillera, southern Spain. Another purpose of this study is to compare sand detrital modes collected from fluvial and coastal environments to data from sands recovered in deep-marine environments on ODP Leg 161, in an effort to clarify the source-to-basin pathways of sandy sediment in the northern Alboran Basin. The onshore and offshore compositional data sets form the basis of an actualistic model for interpreting the provenance of ancient sandstones deposited in sedimentary basins developed during the collisional evolution of the Mediterranean region (e.g., Schwab 1981; Valloni and Zuffa 1984; Critelli and Le Pera 1995, 1998). 


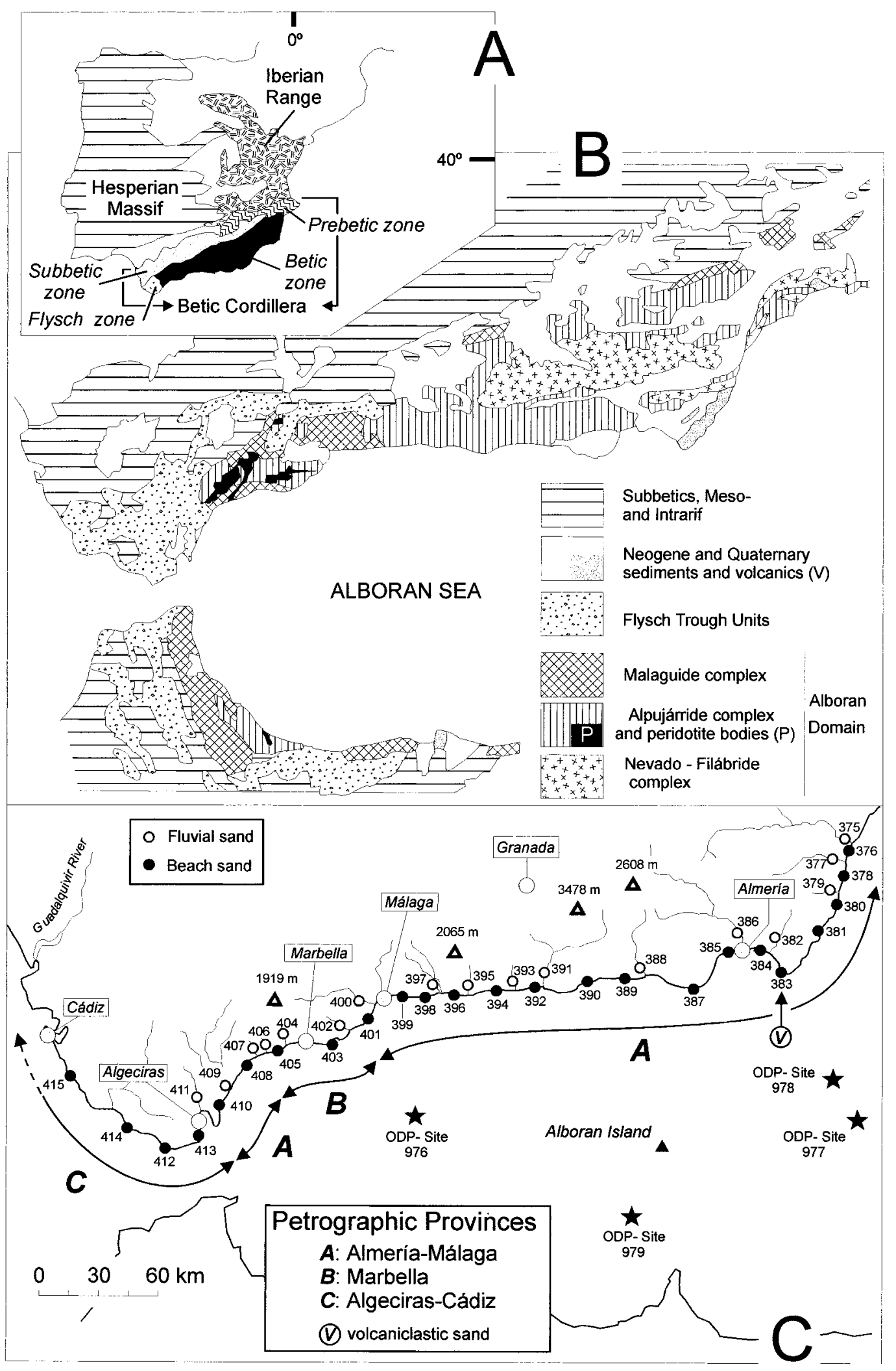

FIg. 1.-Geographic and geologic sketch map (after Balanyá et al. 1998) of the Mediterranean side of the Betic thrust belt. Location of analyzed modern sand samples is shown, as such as location of the ODP Sites 977-979 within the Alboran Sea. 


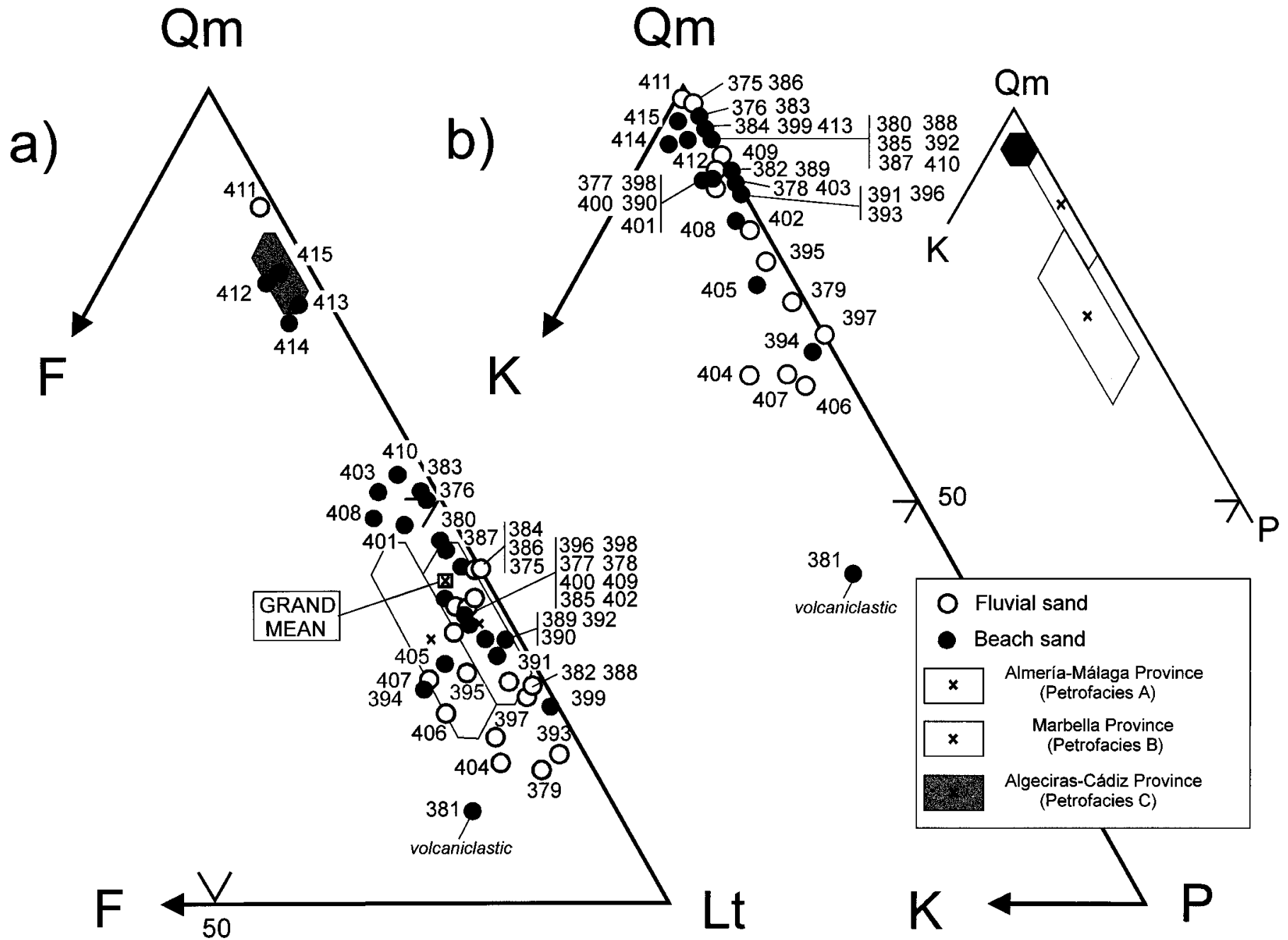

FIg. 2.-QmFLt (a) and QmPK (b) ternary plots of the modern fluvial and beach sand samples of the coastal side of the Betic Cordillera. Polygons are one standard deviation on either side of the mean.

This model will help in understanding ancient sandstone composition from equivalent scenarios.

\section{SETTING}

The southern margin of Iberia is made up of the Betic Cordillera, a Neogene fold-thrust belt, accreted over the Iberian continental block. This chain forms a terrestrial foreland basin system, the Guadalquivir River basin, to the northwest, whereas the collapsed southern margin of the chain is represented by the Alboran Basin (e.g., Weijermars 1991).

Topography of the Betic Cordillera ranges from sea level to $3478 \mathrm{~m}$ (Mount Mulhacen). The northeast to southwest arrangement of the chain is manifested by a nearly continuous alignment of highlands nearly parallel to the coastline. Drainage of the chain is to the northwest and to the south. Channels draining northwest feed the Guadalquivir River, which flows southwest along the foreland basin of the chain (Guadalquivir basin). The southern drainage network consists of short rivers generally less than 50 $\mathrm{km}$ in length that drain directly to the coast. These are steep, high-gradient ephemeral mountain rivers. Occasional catastrophic floods produce rapid transport of sediment to the coast. Sediments contributed by these streams are distributed along the shore by drift currents to the east. In the region of the coast between Málaga and Almería, small delta systems are developed corresponding to the principal river courses of this area (Vélez, Tor- rox, Guadalfeo, Adra, and Andarax rivers). The climate along the coast varies from semiarid to desert (Bsh and BW of Köppen 1901, respectively) with mean annual precipitation varying from less than $200 \mathrm{~mm}$ at the east to near $1000 \mathrm{~mm}$ at the west. Mean annual temperature averages $18^{\circ} \mathrm{C}$ at the coast. Inland climate is colder (Bsk and Csa of Köppen 1901), and even temperate rainy $(\mathrm{Csb})$ in local areas (north of Málaga), where mean annual precipitation exceeds $1600 \mathrm{~mm}$. Under these climatic conditions, we expect chemical weathering to be nearly absent and the erosion regime to be weathering-limited (Johnsson 1993). In addition, high relief and short river courses produce little change in sediment composition during transport, and thus, sand composition may accurately reflect the rock types of the source region (e.g., Cavazza et al. 1993).

The Betic Cordillera is traditionally subdivided into an External Domain, in the north, and an Internal Domain, in the south (Fallot 1948).

The External Domain is subdivided into a Prebetic Zone and a Subbetic Zone, composed of Mesozoic to Tertiary sedimentary rocks, and the Flysch Zone (Fig. 1A, B). The Prebetic Zone is located to the east and northeast of the Subbetic zone. The Subbetic Zone has a northeast-southwest trend and comprises the Atlantic zone of southern Spain. The Prebetic and Subbetic zones include Triassic to Tertiary gypsum, claystone, dolostone, marl, and limestone (Gutierrez-Mas et al. 1991). The Flysch Zone (Gibraltar Field Complex) crops out in the Gibraltar Promontory and includes Cre- 
TABLE 1.-Site location of sand samples used for the compositional study.

\begin{tabular}{|c|c|c|}
\hline \multicolumn{2}{|c|}{ Sample Environment } & \multirow[t]{2}{*}{ Site Location } \\
\hline 375 & Fluvial & \\
\hline 376 & Beach & Puerto Rey (c $5 \mathrm{~km}$ southwest from Río Almanzora river mouth) \\
\hline 377 & Fluvial & Río de Aguas (c .3 km from the mouth) \\
\hline 378 & Beach & Pueblo Índaol (c $.6 \mathrm{~km}$ southwest from Río de Aguas river mouth) \\
\hline 379 & Fluvial & Río Carboneras ( $c .1 \mathrm{~km}$ from the mouth) \\
\hline 380 & Beach & Carboneras (La Puntica; c .5 km southwest from Río Carboneras river mouth) \\
\hline 381 & Beach & Las Negras \\
\hline 382 & Fluvial & Río Morales ( $c .3 \mathrm{~km}$ from the mouth) \\
\hline 383 & Beach & Salinas del Cabo de Gata \\
\hline 384 & Beach & El Alquián \\
\hline 385 & Beach & Punta del Río (Almería: c .2 km west from the Río Andarax river mouth) \\
\hline 386 & Fluvial & Río Andarax (Almería; c $3 \mathrm{~km}$ from the mouth) \\
\hline 387 & Beach & Punta Sabinar \\
\hline 388 & Fluvial & Río Adra (c .2 km from the mouth) \\
\hline 389 & Beach & Adra (c $.2 \mathrm{~km}$ wet from Río Adra river mouth) \\
\hline 390 & Beach & Castillo de Baños \\
\hline 391 & Fluvial & Río Guadalfeo (c $.4 \mathrm{~km}$ from the mouth) \\
\hline 392 & Beach & La Caleta (c $.3 \mathrm{~km}$ west from Río Guadalfeo river mouth) \\
\hline 393 & Fluvial & Río Verde (c .2 km from the mouth) \\
\hline 394 & Beach & Punta de la Mona (c $.4 \mathrm{~km}$ west from Río Verde river mouth) \\
\hline 395 & Fluvial & Río Torrox (c.2 km from the mouth) \\
\hline 396 & Beach & Lagos (c .5 km west from Río Torrox river mouth) \\
\hline 397 & Fluvial & Río Vélez (c $.2 \mathrm{~km}$ from the mouth) \\
\hline 398 & Beach & Almavate ( $c .4 \mathrm{~km}$ west from the Río Velez river mouth) \\
\hline 399 & Beach & La Cala del Moral (east of Málaga) \\
\hline 400 & Fluvial & Río Guadalhorce (c. $3 \mathrm{~km}$ from the mouth; Málaga) \\
\hline 401 & Beach & Lido (c .4 km southwest from the Río Guadalhorce river mouth) \\
\hline 402 & Fluvial & Río Fuengirola ( $c .2 \mathrm{~km}$ from the mouth) \\
\hline 403 & Beach & Torre Calahonda ( $c .8 \mathrm{~km}$ southwest from the Río Fuengirola river mouth) \\
\hline 404 & Fluvial & Río Verde de Marbella ( $c .2 \mathrm{~km}$ from the mouth) \\
\hline 405 & Beach & San Pedro de Alcantara (c $.3 \mathrm{~km}$ southwest from the Río Verde de Marbella) \\
\hline 406 & Fluvial & Río Guadalmina (c $.3 \mathrm{~km}$ from the mouth) \\
\hline 407 & Fluvial & Río Guadalmansa (c $.2 \mathrm{~km}$ from the mouth) \\
\hline 408 & Beach & Punta del Castor. Estepona (c $.2 \mathrm{~km}$ southwest from the Río Guadalmansa) \\
\hline 409 & Fluvial & Río Guadiaro (c $.4 \mathrm{~km}$ from the mouth) \\
\hline 410 & Beach & La Atunara (c $.5 \mathrm{~km}$ southwest from the Río Guadiaro) \\
\hline 411 & Fluvial & Río Guadarranque (c.10 km from the mouth) \\
\hline 412 & Beach & Punta de Tarifa \\
\hline 413 & Beach & Getares \\
\hline 414 & Beach & Zahara de Los Atunes \\
\hline 415 & Beach & La Barrosa (south of Sancti Petri) \\
\hline
\end{tabular}

taceous to lower Miocene quartzose turbidite sequences (Aljibe and Algeciras Units, and unnamed Cretaceous sandstone) and clays (GutierrezMas et al. 1991).

The Internal Domain (Alboran Domain or Betic Zone) includes stacked thrust sheets composed of metasedimentary and sedimentary rocks of Paleozoic to Tertiary age (Fig. 1A, B). The Internal Domain is subdivided into the Nevado/Filábride Complex and the Higher Betic Nappe. The latter is exposed only in the eroded core of the Betic ranges. The Nevado-Filábride Complex includes Paleozoic garnet-bearing and chloritoid-garnet mica schists and quartzite, local cordierite, andalusite, sillimanite, and garnet gneiss (Lundeen 1978), Paleozoic to Triassic mica schist, marble, calcschist, albite-epidote amphibolite, metavolcanic and serpentinite rocks, and Triassic calcareous breccia and dolostone (Weijermars 1991, and references cited therein).

The Nevado-Filábride Complex is overlain by the Higher Betic Nappe. The latter consists of two main thin thrust sheets, the Alpujárride and Málaguide complexes. In a few locations Triassic metasedimentary terranes (Almágride Complex) separate the Nevado-Filábride Complex from the Alpujárride Complex.

The Alpujárride Complex includes Paleozoic (pre-Silurian?) quartzite, mica schist, garnet-bearing schist, epidote schist, and marble; Permian-toTriassic phyllite, quartzite, and graphite-bearing and garnet-bearing schist with interbedded marble and metabasalt; and Triassic gypsum, limestone, and dolostone. The Alpujarride Complex, in the westernmost part of the Betic zone, includes the Ronda Peridotite Complex, the world's largest exposure of upper-mantle rocks $\left(\sim 300 \mathrm{~km}^{2}\right)$. The Ronda Complex includes peridotite, olivine gabbro, and spinel or garnet pyroxenite (Dickey 1970) that has been minimally altered by serpentinization (Lundeen 1978; Weijermars 1991, and references cited therein).

The Maláguide Complex consists of unmetamorphosed to very lowgrade metamorphic carbonate rocks, gypsum, chert, sandstone, shale, and conglomerate, ranging in age from Silurian to early Miocene.

The tectonic units of the Higher Betic Nappe are unconformably covered by early Miocene to Quaternary clastic, carbonate, and evaporite rocks.

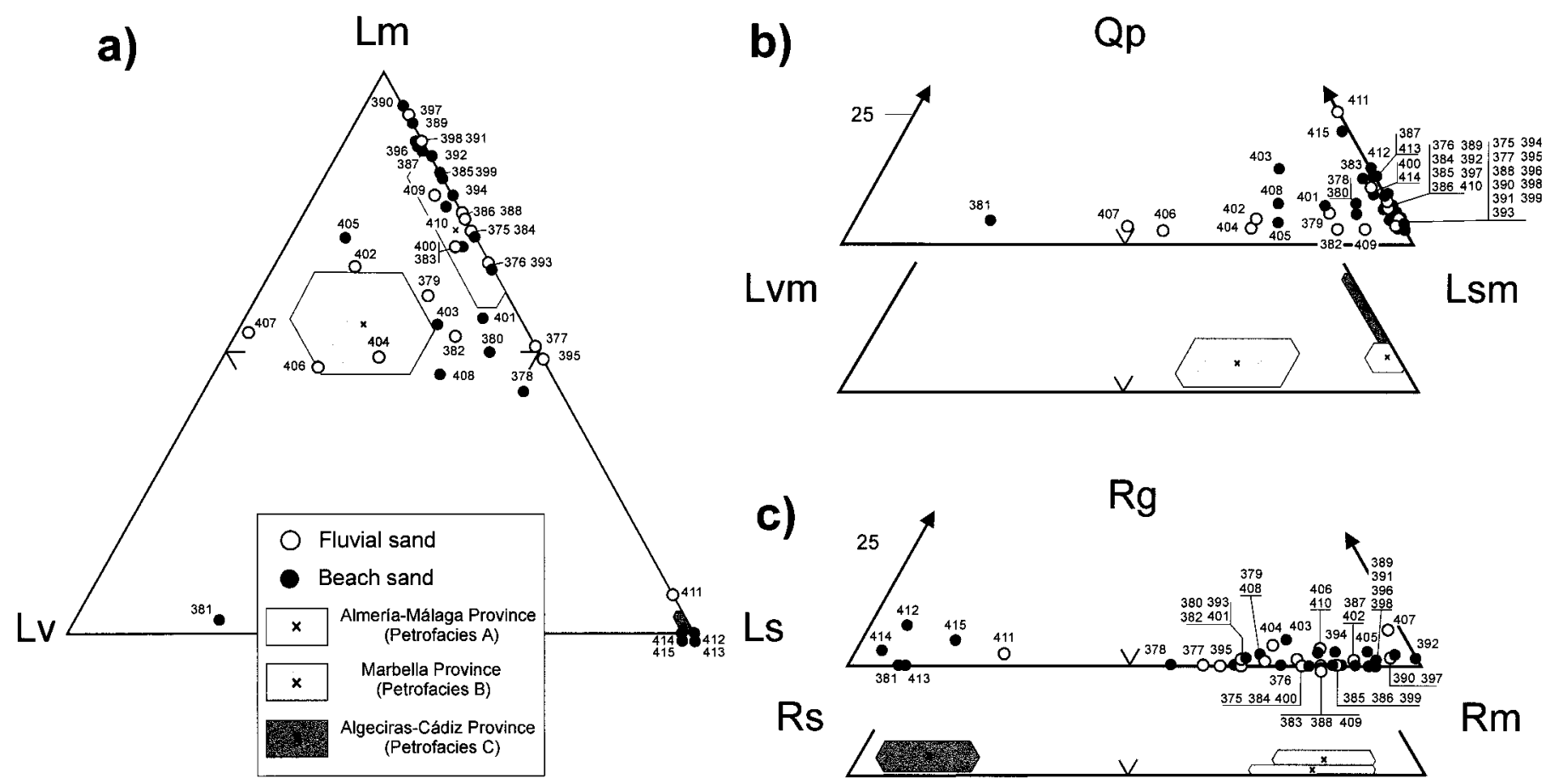

FIg. 3.-LmLvLs (a), QpLvmLsm (b), and RgRsRm (c) ternary plots of the modern fluvial and beach sand samples of the coastal side of the Betic Cordillera. Polygons are one standard deviation on either side of the mean. 

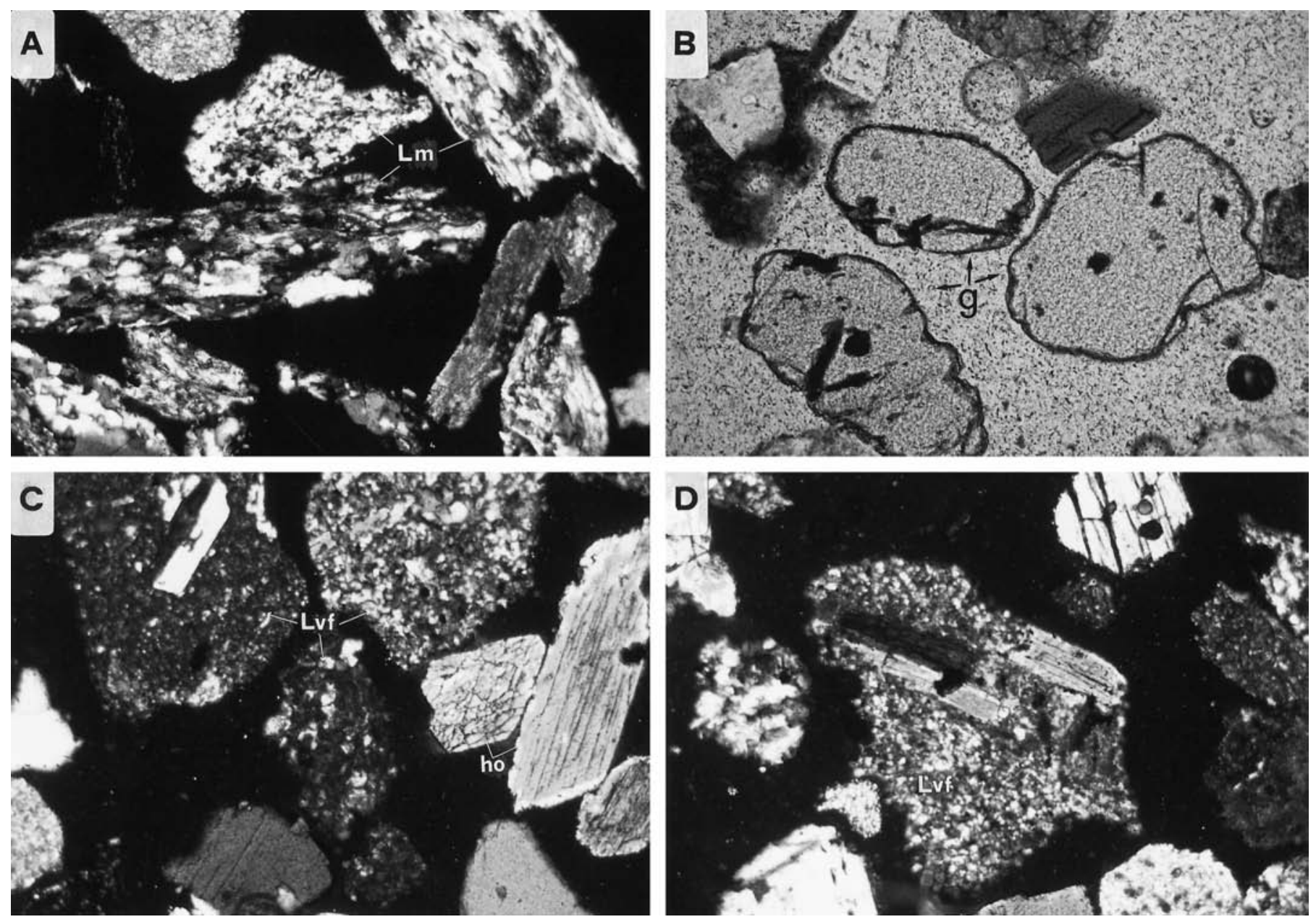

FIg. 4.-Photomicrographs of diagnostic grains for the modern fluvial and beach sand petrofacies of the coastal side of the Betic Cordillera. A, B) Phyllite grains (Lm) and garnet grains from the metamorphic-sedimenticlastic petrofacies (Almería-Málaga Province). C, D) Felsitic volcanic lithic fragments (Lvf) and single brown hornblende (ho) crystals from the volcaniclastic sand petrofacies (Las Negras beach). E, F) Phaneritic (Rp) and aphanitic (Lp) peridotite rock fragments with pyroxene (px) and amphibole (am) crystals from the ultramaficlastic petrofacies (Marbella Province). G, H) Multicyclic quartz (q) grains with inherited overgrowths and siliciclastic sedimentary lithic fragments (Lss, quartzsiltstone) from the quartzose petrofacies (Algeciras-Cádiz Province). A, C-H = crossed nicols; B = plane-polarized light. Field size of photomicrograph: $1 \times 0.7 \mathrm{~mm}$.

Local outcrops of Miocene (15 to $7 \mathrm{Ma}$ ) calcalkaline (andesite to rhyolite) volcanic and volcaniclastic rocks occur along the coast from Cabo de Gata to Carboneras (Fig. 1; Weijermars 1991, and references cited therein).

\section{METHODS}

Forty-one sand samples were collected from fluvial and coastal environments (17 fluvial and 24 beach samples; Table 1), covering an area of more than $400 \mathrm{~km}$ in length (Fig. 1C). The 17 fluvial samples were collected from the active main channel and bars in the inner reaches of the channels. Beach sands were collected from high-tide berms at 24 localities (Table 1); each beach sand sample was collected 2000-8000 m southward of the corresponding river mouth (Fig. 1C).

All sand samples were washed using $\mathrm{H}_{2} \mathrm{O}_{2}$ to remove organic matter, air dried, and sieved (using 1-phi intervals). The $0.25-0.50 \mathrm{~mm}$ size fraction was used to prepare thin sections, which were etched with HF and stained by immersion in sodium cobaltinitrite solution to allow the identification of feldspars grains. Alizarine and potassium Fe-cyanide were also used for identification of carbonate grains. Three hundred points were counted on each thin section using the Gazzi-Dickinson method (Ingersoll et al. 1984). Point-count raw results and recalculated modal results are available in JSR's digital archives (see Acknowledgments).

\section{RESULTS}

\section{Principal Compositional Groupings}

We use detrital modes (expressed by suite means and standard deviation fields) to determine compositional variability of local drainage patterns, and the influence of source rock type on local coastal drainages and on shoreline and nearshore sand composition. The sand samples are poorly to well sorted and consist of coarse- to-medium-size sand grains that are angular to rounded. All of the sand samples are quartzolithic (grand mean Qm39 F5 Lt56), ranging from highly quartzose to lithic rich (Fig. 2). Monocrystalline quartz ranges from $11 \%$ to $85 \%(\mathrm{QmFLt} \% \mathrm{Qm})$, and lithic grains range from $13 \%$ to $79 \%(\mathrm{QmFLt} \% \mathrm{Lt})$, whereas feldspars are only a minor component. Lithic fragment types are diverse, and include all source rocks of the southern flank of the Betic Cordillera: sedimentary (both siliciclastic and carbonate), metamorphic (low- to medium-grade), volcanic, and mantle-derived (peridotite, gabbro, serpentinite) rocks.

Dense minerals range from 0 to $23 \%$ of the counted grain totals. Several species were recognized during modal analysis. Garnet and opaque minerals are present in most of the samples. Of special note is the presence of abundant amphibole (tremolite and other amphiboles), pyroxene, and garnet in the samples taken along the coast of Málaga (samples 402 to 408). 

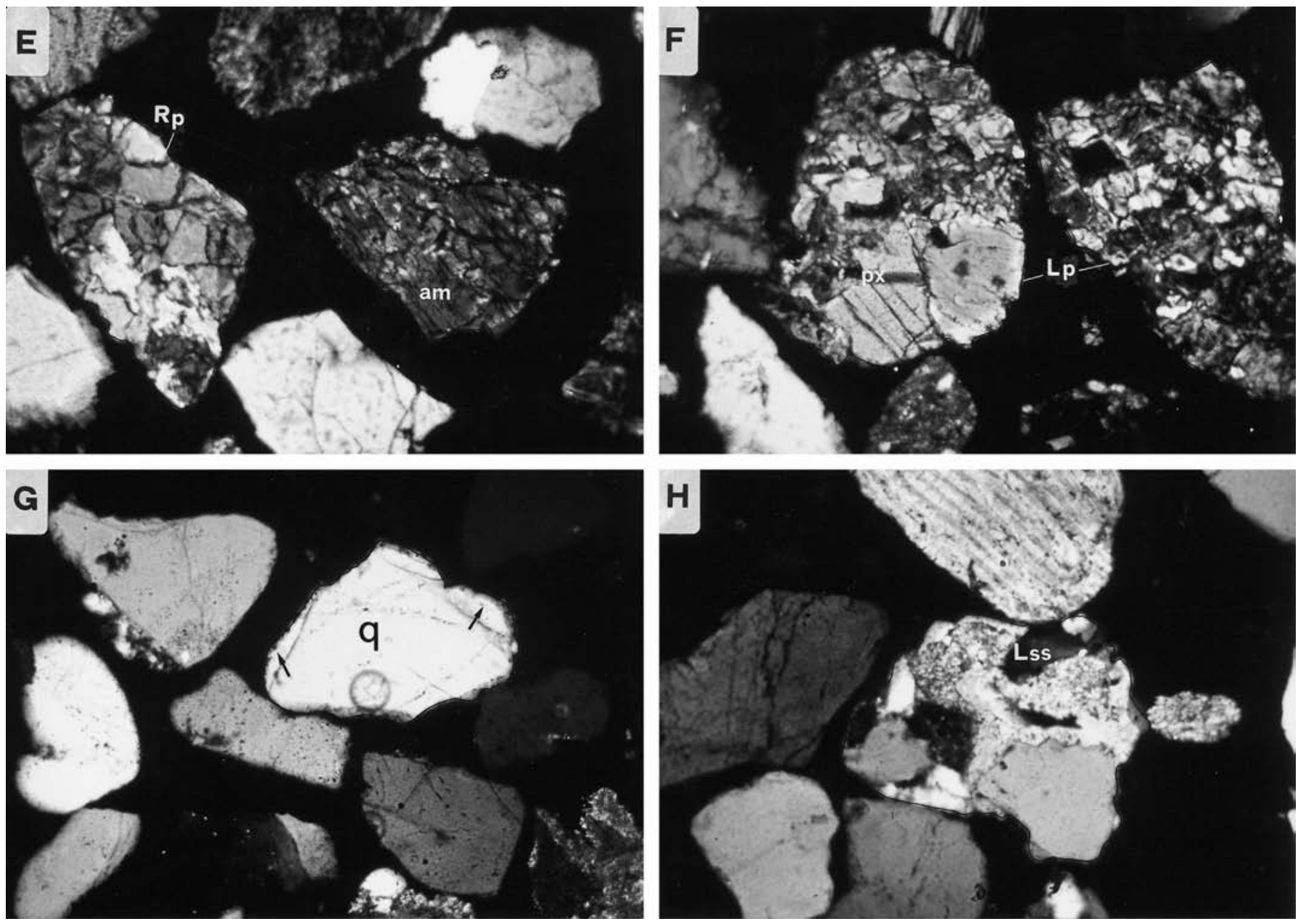

FIg. 4.-Continued

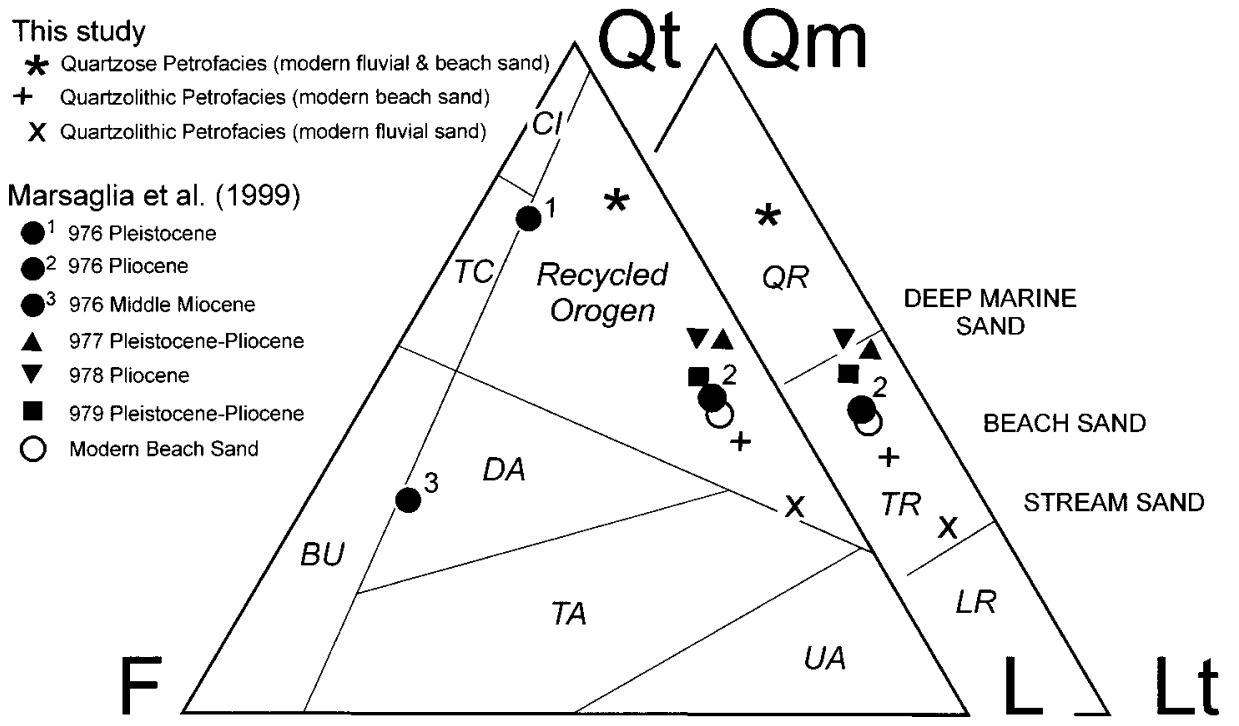

FIG. 5.-Mean sand compositions for the three modern onshore (fluvial and beach environments) sand petrofacies of the Betic coast, and for the Sites 976, 977, 978, and 979 and modern beach sand samples studied in Marsaglia et al. (1999) plotted on QmFLt and QtFL ternary diagrams with superimposed provenance fields of Dickinson (1985) $(\mathrm{CI}=$ craton interior; $\mathrm{TC}=$ transitional continent; $\mathrm{BU}$ $=$ basement uplift; $\mathrm{DA}=$ dissected $\operatorname{arc} ; \mathrm{TA}=$ transitional arc; $\mathrm{UA}=$ undissected $\operatorname{arc} ; \mathrm{QR}=$ quartzose recycling; TR $=$ transitional recycling; $\mathrm{LR}=$ lithic recycling). 


\section{Petrofacies Characteristics}

The fluvial and beach sands of the Betic Cordillera are subdivided into three distinctive petrofacies based on visual inspection of the data. These three compositional groupings (Figs. 2, 3) correspond with the physiographic provinces of the Sierra de los Filabres, Sierra Nevada, and Málaga Mountains, here named Almería-Málaga Province (metamorphic-sedimenticlastic quartzolithic petrofacies), the Serrania de Ronda, named Marbella Province (ultramaficlastic quartzolithic petrofacies), and the southwestern end of the Betic coast, named the Algeciras-Cádiz Province (quartzose petrofacies). Only one sand sample (381) is volcaniclastic (Cabo de GataCarboneras province), and it will be described without formal definition of petrographic province.

Metamorphic-Sedimenticlastic Quartzolithic Petrofacies (AlmeríaMálaga Province).-This quartzolithic petrofacies corresponds to the fluvial systems draining the Sierra de los Filabres, the Sierra Nevada, and part of the Málaga Mountains, and their related coastal system. This petrofacies extends from the northeastern coast of Almeria to Málaga (samples from 375 to 401; except the volcaniclastic sand sample 381), and eastern coast of Algeciras (samples 409 and 410). Sand of this petrofacies has abundant lithic grains and quartz (Qm34 $\pm 10 \mathrm{~F} 4 \pm 3$ Lt62 \pm 9 ; Fig. 2), and feldspar is minor and dominantly plagioclase. Aphanitic lithic fragments (Lm72 \pm 14 Lv2 4 Ls26士13; Fig. 3) include abundant metasedimentary (phyllite, schist, minor quartzite, and fine-grained gneiss; Fig. 4A) and sedimentary (dolostone and limestone grains, siltstone, and fine-grained sandstone) grains. Only few samples $(378,379,380,382$, and 383), located in the northeastern coast of Almeria, also contain volcanic lithic fragments. These grains dominantly display a felsitic texture and were derived from the Miocene volcanic sequence cropping out at Cabo de Gata.

The abundant metasedimentary and sedimentary lithic fragments in this petrofacies are derived from the Nevado-Filábride, Alpujárride, and Málaguide Complexes, and Neogene sedimentary sequences. In particular, the metasedimentary lithic fragments, represented by phyllite, mica schist, graphitic schist, epidote schist, garnet-bearing schist, gneiss, and quartzite fragments, correspond with the Paleozoic metasedimentary successions of the Nevado-Filábride, Alpujárride, and Málaguide complexes. Gneissic fragments are derived from interbedded gneissic rocks of the Nevado-Filábride Complex, and from the Blanca Unit underlying the Ronda Peridotite (e.g., Lundeen 1978). These metasedimentary rocks contain abundant garnet, epidote, and other dense minerals typical of metamorphic rocks, which are abundant components of sand from their associated fluvial and beach systems (Fig. 4B).

Serpentinite and serpentine schist also are present, particularly in two samples from the southern coast of Málaga and related fluvial course (samples 400 and 401). This river cuts across the Málaguide and Alpujárride Complexes and the Ronda Peridotite Complex, the latter representing the key source for these ultramafic lithic grains.

Volcaniclastic Sand Petrofacies.-Only one sample, from Las Negras beach, is volcaniclastic. In addition to volcanic lithic fragments, it contains fragments of detrital carbonate (sample 381). The volcanic lithic fragments that dominate this sample (LmLvLs 75\% Lv) exhibit mainly felsitic granular to felsitic seriate textures (Fig. 4C, D). Hornblende crystals are also abundant (Fig. 4C), and sanidine and sodic to intermediate zoned plagioclase are present. The abundance of felsitic lithic fragments, in combination with the presence of hornblende and sanidine crystals, suggests a dominantly dacitic to rhyodacitic volcanic source. The carbonate fragments in this sand, are mainly recycled from mid-Late Tortonian sedimentary sequences that partly cover the volcanic sequence.

Ultramaficlastic Quartzolithic Petrofacies (Marbella Province).This petrofacies corresponds to the four main fluvial systems draining the Serrania de Ronda and their relative river mouths, extending from Torremolinos to the western coast of Marbella (samples from 402 to 408; Table 1; Fig. 1). These quartzolithic sands (Qm32 \pm 12 F10 \pm 3 Lt58 \pm 11 ; Fig. 2) have high percentages of serpentinite lithic fragments exhibiting cellular texture, fine-grained peridotite lithic fragments, and minor serpentine schist fragments (Fig. 4E, F). More frequently, peridotite fragments occur as coarse-grained (phaneritic) fragments of amphibole, pyroxene, and rare plagioclase (Fig. 4E). Olivine crystals are apparently not preserved within the fragments. The sand samples also include abundant fragments of phyllite, schist, and fine-grained gneiss, whereas sedimentary lithic fragments are minor.

A remarkable feature of this petrofacies is the abundance of ultramafic rock fragments such as peridotite and serpentinite, and diagnostic ultramafic minerals such as pyroxene, amphibole, and serpentine. The Ronda Complex is the source terrane of the ultramafic debris in this petrofacies. Particularly, sand from the Guadalmina (sample 406) and Guadalmansa (sample 407) rivers has a total ultramafic contribution of over $50 \%$ of the counted grains (this ultramafic total is the sum of serpentinite, peridotite, and serpentine schist lithic fragments, single mafic dense minerals, and plagioclase and dense minerals in coarse-grained peridotite and gabbro rock fragments). However, metasedimentary rocks in the other tectonic units also contribute significantly to the sand population of both the rivers and beaches.

Quartzose Petrofacies (Algeciras-Cádiz Province).-This petrofacies

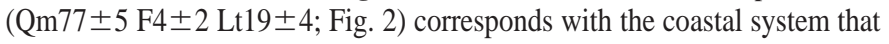
lies between Algeciras and Cádiz. The quartz content of these samples is high, ranging from $71 \%$ to $85 \%(\mathrm{QmFLt} \% \mathrm{Qm})$. Feldspar is minor, and lithic fragments include dominantly siliciclastic and carbonate sedimentary fragments. Single quartz grains are well-rounded, occasionally exhibiting overgrowths (Fig. 4G), consistent with a recycled origin. Sedimentary lithic fragments include quartz siltstone, and fine-grained quartzarenite (Fig. 4H), in addition to abundant limestone and minor dolostone fragments. The abundant recycled quartz grains and fragments of quartzose sandstone and siltstone are derived from the flysch terranes of the Gibraltar Arc, which include dominantly Cretaceous to lower Miocene quartzarenite turbiditic sequences (Cretaceous flysch; Aljibe and Algeciras Units; Gutierrez-Mas et al. 1991). Limestone and dolostone grains document provenance from Triassic to Cretaceous units of the Subbetic Zone (Gutierrez-Mas et al. 1991).

\section{DISCUSSION}

\section{The Recycled-Orogen Provenance Sand Suite}

Quantitative detrital modes of sand and sandstones are used to help identify the tectonic setting of ancient basins, because of the close relationship between sand composition and the tectonic setting of the sand source terranes (e.g., Dickinson 1985, 1988; Valloni 1985). The typical sand suite derived from a fold-thrust belt, like the Betic Chain, is quartzolithic (e.g., Dickinson 1985; Schwab 1986; Critelli and Ingersoll 1994; Critelli and Le Pera 1995, 1998). Detrital modes of such sand(stone) suites were used by Dickinson et al. (1983) to define the recycled-orogen provenance field on a QFL diagram; this field can be further subdivided into a "quartzose," "transitional" and "lithic" subgroup on a QmFLt ternary plot (Dickinson 1985). The quartz-rich quartzolithic sand suite is typically derived by mixing cratonic and fold-thrust belt sediment, or by recycling of previously accreted quartzose sediment sequences (Schwab 1986). The transitional and lithic quartzolithic sand suites are derived mainly from metasedimentary and sedimentary strata previously accreted within the fold-thrust belt, or from uplifted subduction complex terranes (Dickinson 1985; Le Pera and Critelli 1997; Garzanti et al. 1998; Garzanti et al. 2000).

The modern onshore sand of southern Spain is a typical example of an actualistic sand petrofacies that plots in the recycled-orogen provenance group, with distinctive compositions reflecting the "quartzose," "transitional," and "lithic" sands subgroups. Furthermore, this modern example provides information on the geographic distribution of petrofacies by depositional environment (e.g., stream, beach, and deep basinal settings), and allows direct correlation of sand composition to outcropping lithologies. 
We first discuss the modern stream and beach sand detrital modes presented in this paper (from west to east) and then relate them to the detrital modes of deep-marine sand recovered during ODP drilling in the Alboran Basin.

\section{Fluvial and Beach Sand Petrofacies}

The quartzose sand petrofacies of the southern end of Spain (AlgecirasCádiz Province) are derived by recycling of Cretaceous and Oligocene to Miocene (Aljibe and Algeciras units) quartzarenite turbiditic strata, and Mesozoic carbonate strata. The presence of multicyclic detritus is indicated by abundant well-rounded quartz grains, quartz grains with preserved rounded overgrowths, and fragments of carbonate-cemented quartzose siltstone and fine-grained quartzarenite. This quartzose petrofacies reflects a dominant derivation from Tertiary craton-derived clastic sequences deposited during early developmental stages of the Betic and Rif foreland basin system (e.g., Cazzola and Critelli 1987; Guerrera et al. 1993).

The Mediterranean coast of Spain is characterized by a large physiographic province associated with the Betic fold-thrust belt. The composition of sand derived from this province is typically "lithic to transitional" quartzolithic. The Betic coastal stretch from Almeria to Algeciras includes two distinct quartzolithic petrofacies, a metamorphic-sedimenticlastic (Almería-Málaga Province) and an ultramaficlastic (Marbella Province). The metamorphic-sedimenticlastic quartzolithic petrofacies is derived from metasedimentary and sedimentary sequences of the stacked tectonostratigraphic terranes of the lesser and higher Betic units. The ultramaficlastic quartzolithic petrofacies of the Marbella Province is derived mainly from the Ronda Peridotite Complex, which supplies abundant peridotite, gabbro, and serpentinite detritus to the fluvial and coastal environment. These two onshore quartzolithic petrofacies essentially constitute the detrital supply from tectonostratigraphic terranes of the Betic fold-thrust belt.

The quartzolithic petrofacies derived erosion of the Betic fold-thrust belt thus reflects a recycled-orogen provenance. In the case of these petrofacies, it is possible to constrain the close relationship between the stacked source lithologies and their occurrence within the sand.

\section{Alboran Basin Sand: Comparing Onshore and Offshore Sand Composition}

Three of the sand-bearing sites drilled during ODP Leg 161 in the Alboran Basin contain sand likely derived from the coastal areas of Spain that were sampled in this study (Fig. 1). We discuss their detrital modes as determined previously (Latter 1998; Marsaglia et al. 1999) and compare them to the more extensive onshore data base collected for the present study.

The sandy sections at these sites range in age from Miocene to Pleistocene. The very fine- to fine-grained sand is present in isolated pods (burrow fills), and thin laminae to thin beds, some exhibiting scoured bases and normal grading. The sand was likely transported basinward via submarine-channel systems extending off the Betic coast. Once deposited by turbidity currents, the sediment may have been winnowed and reworked by bottom-current activity (Comas et al. 1996). Coarser-grained sand is limited to the few Miocene samples examined. The depositional settings for this lowstand material remain equivocal, but they are possibly marginal marine to nonmarine (Comas et al. 1996).

Several offshore petrofacies were defined by Marsaglia et al. (1999) in the sandy deposits cored at these ODP sites. They used the detrital modes of a small number (10) of beach sand samples to help clarify the Alboran Basin sand provenance. The offshore petrofacies correspond, to some degree, with the modern petrofacies defined in this study.

Here we compare these compositional groups on more general QtFL and QmFLt ternary plots because of slight differences in definition of lithic fragments between Marsaglia et al. (1999) and this study. For example, Marsaglia et al. (1999) treated the serpentine-serpentinite as metamorphic rock fragments, whereas in this study they were tallied with volcanic debris. Also there appear to be some differences in the proportions of metamorphic and sedimentary rock fragments in corresponding beach sand samples; these differences could be a product of category definitions and subtle textural variations in shale-slate-phyllite fragments as discussed in Dorsey (1988). Despite these differences in lithic-fragment categories, the grand QtFL and QmFLt means for both data sets are fairly similar (Fig. 5).

The onshore metamorphic-sedimenticlastic quartzose petrofacies corresponds with the composition of sand from the Pliocene to Pleistocene section at Site 977 and the Pliocene sections at 978 and 976. Based on submarine physiography and sparse beach sand compositions, Marsaglia et al. (1999) favored an Andarax River source via the Almeria channel for this sand at Sites 977 and 978. The detailed beach and fluvial data set collected for this study also supports such a source.

Site 976 is situated south of Málaga, more proximal to the onshore areas with the ultramafic quartzolithic petrofacies and the quartzose petrofacies than 978 and 979. There is, however, no exact equivalent of the ultramafic quartzolithic petrofacies in the offshore sandy units. Only one offshore sample, the youngest Pliocene sandstone recovered at Site 976, contained a significant (5\% of total grains counted) quantity of serpentine. Other samples stratigraphically below this serpentine-rich sample contained only traces of serpentine. The upsection increase in serpentine may be a function of the development of onshore drainage across increasingly larger areas of peridotite outcrop.

The onshore quartzose petrofacies is most similar in composition to the Pleistocene sand recovered at Site 976, but the offshore sand is much more enriched in feldspar (Fig. 5). Marsaglia et al. (1999) hypothesized a Gibraltar area source for this sand. These source supplies were transported eastward during periods of estuarine circulation generated by surface-water freshening during glacial minima. The beach and stream sand data collected in this study strengthen this argument.

One of the surprising results of the Marsaglia et al. (1999) study was the limited volcanic component in the deeper part of the Alboran Basin, where basin highs are generally thought to be volcanic in nature. In terms of modern outcrops, volcanic rocks are limited to the easternmost part of the Betic zone of southern Spain (Fig. 1B). These units produce sands that exhibit a variety of volcanic lithic textures as indicated by the mix of felsitic, microlitic, and lathwork textures shown by sample 381 in this study, and the vitric and crystal components in a beach sand sample examined by Marsaglia et al. (1999). The volcanic components in the three Miocene samples indicate altered vesicular vitric fragments at Site 976 and minor felsitic fragments at Site 977.

A fourth ODP site (979), drilled more proximal to the African margin, provides some additional information on the variability and controls of sand composition across the basin. The Pleistocene to Upper Pliocene sand deposited at Site 979 was generally more enriched in sedimentary lithic fragments than sand from the northern sites. This is not as we expected, in that onshore African outcrops are dominated by sedimentary units. Marsaglia et al. (1999) noted that there was some evidence to suggest an unroofing history of that margin, with older samples enriched in sedimentary fragments and younger sands tending to be more enriched in metamorphic lithic fragments. In addition, a few samples contained unaltered sand-size glass shards, produced during volcanic activity either on the African mainland or the nearby Alboran Ridge. Despite these variances in lithic types the overall proportion of QtFL components was very similar to those of the other sites from the northern part of the basin (Fig. 5).

\section{Compositional Trends among Stream, Beach, and Basinal Sand Samples}

As indicated on Figure 5, there are distinct compositional differences among offshore and onshore sand populations in the Betic province. On average, the stream sand samples are more lithic rich, and the beach sam- 
ples more quartz rich. The deep marine sand samples are even more quartzose than even the beach samples. This facies-related compositional trend is similar to that documented in fluvial, beach, and turbidite facies of the Pennsylvanian Minturn Formation of Colorado (Kairo et al. 1993), of the Tyrrhenian (Le Pera and Critelli 1997) and Ionian margins of Calabria (Critelli and Le Pera 2001), and in southern California (Critelli et al. 1997). In general, the offshore sands are finer grained than their onshore counterparts, suggesting that some of the compositional shift to more quartzose sand in basinal settings could also be related to compositional fractionation by grain size. Thus, the onshore modern quartzose petrofacies sand exhibits a composition distinct from that of the possible offshore Pleistocene equivalents at Site 976 (Fig. 5). The latter are much more enriched in feldspar, and finer grained (Marsaglia et al. 1999). This trend could be explained by concentration of feldspar in the finer grain-size fraction (Odom et al. 1976). Climate, an important control on the survival of feldspar detritus in the rock record (e.g., Le Pera et al. 2001), could also have played a role in the preferential concentration of feldspar in the Pleistocene at Site 976. If sand delivery to this site was tied to glacial cycles as proposed by Marsaglia et al. (1999), then their higher feldspar content also could be climate related. Higher feldspar content could be linked to periods of less intense chemical weathering in the source area. The lesser quantity of serpentine in the offshore sections also could be a function of transport distance. The softer serpentine might break down and be preferentially concentrated in the silt size fraction.

\section{CONCLUSIONS}

This study of modern fluvial and coastal sands from the Betic Cordillera (southern Spain) shows how various types of petrofacies derived from a recycled-orogen system can be discriminated among the main structural domains of a chain.

Three onshore petrofacies have been recognized, and they plot in the recycled-orogen provenance compositional field and the lithic to transitional to quartzose recycled subfields of Dickinson (1985). They vary from lithic subfield, to transitional and quartzose subfields depending on their source rocks in the Betic foreland fold-thrust belt, where primary and recycled source rocks are interfingered.

The metamorphic-sedimenticlastic quartzolithic petrofacies (AlmeríaMálaga Province) consists mainly of sands with abundant lithic (metasedimentary and sedimentary) fragments and quartz grains (mean of Qm34F4Lt62 and Lm72Lv2Ls26). Sources for this petrofacies are the Paleozoic metasedimentary successions of the Nevado-Filábride, Alpujárride, and Málaguide complexes, and the Neogene sedimentary sequence. This mixed metamorphic-sedimenticlastic petrographic province is the widest province developed on the Betic coast, running from the northeastern coast of Almeria to Málaga. This petrofacies is also identified at the eastern coast of Algeciras (Fig. 1). A volcaniclastic sand petrofacies (Qm11F16Lt73) is developed locally in the Cabo de Gata area (Las Negras beach), and is derived from the erosion of Miocene calcalkaline volcanic sources.

The ultramaficlastic quartzolithic petrofacies (Marbella Province) is characterized by peridotite- and serpentinite-rich sand with abundant Ferromagnesian minerals (amphibole, pyroxene, and serpentine) (mean of Qm32F10Lt58 and Lm55Lv26Ls19). The spatial distribution of this petrofacies is from Fuengirola to Estepona localities, around Marbella, and reflects derivation mainly from mantle-derived sources (Ronda Peridotite Complex).

The quartzose petrofacies (Algeciras-Cádiz Province) sand (mean of Qm77F4Lt19) is sedimenticlastic in origin with a predominance of quartz siltstone, quartzarenite, limestone, and minor dolostone as the main sedimentary lithics (mean of Lm1Lv1Ls98). The dominant sources are the quartzose flysch units of the Gibraltar Arc, with minor contributions of the sedimentary sequence from the Subbetic Zone. This petrofacies appears in the Atlantic side of the Betic coast, between Algeciras and Cádiz. This composition could represent the ultimate western Betic provenance before sedimentary processes of the Guadalquivir river mouth system control the coastal sediment dispersal.

The onshore petrofacies are closely correlative with turbidite sand petrofacies of the Alboran Basin. Detailing the geographic distribution of the onshore petrofacies provides a suitable basis for interpreting the Miocene to Pleistocene sand dispersal in the deep-marine Alboran Basin and unraveling the tectonic evolution of the Betic orogen. These modern quartzolithic petrofacies are used to interpret analogous ancient collisional sandstone petrofacies of the Alpine orogenic belt of the western-central Mediterranean region. In addition, future works in similar geotectonic situations will benefit by the use of defined orogenic petrofacies.

\section{ACKNOWLEDGMENTS}

This work was funded by a 2001-2002 Bilateral Italian Consiglio Nazionale delle Ricerche (CNR)-Spanish Consejo Superior de Investigationes Cientificas (CSIC) grant (Project: "Composition, Provenance and Dispersal Pathways of Modern and Recent Sediments of the Central-Western Mediterranean Sea: Implications for Paleogeographic and Geodynamic Interpretations of Sedimentary Basins;"' Resps. J. Arribas and S. Critelli). The paper is also a contribution to the Spanish DGICYT project PB93-0178 (Resp. J. Arribas), to the CNR-Istituto di Ricerca per la Protezione Idrogeologica (Cosenza) project "The effects of climate, morphology and geology on generation and transport of sediment to the coastal and marine environments of the Mediterranean Sea" (Resp. E. Le Pera), and to the MURST ex-60\% project "Evoluzione paleogeografica e paleotettonica della Catena orogenica alpina in Italia Meridionale" (Resp. S. Critelli). E. Le Pera was supported by C.N.R. Advanced Fellowship at the Universidad Complutense de Madrid, during 1998. K.M. Marsaglia and K.K. Latter were supported by a grant from the National Science Foundation administrated by the Joint Oceanographic Institutions. We are grateful to M. Johnsson, M.J. Kraus, G.A. Smith, J.B. Southard and G.G. Zuffa for reviewing the manuscript. The data described in this paper have been archived, and are available in digital form, at the World Data Center-A for Marine Geology and Geophysics, NOAA/NGDC, 325 Broadway, Boulder, CO 80303; (phone: 303-497-6339; fax: 303-497-6513; E-mail: wdcamgg @ngdc.noaa.gov; URL: http://www.ngdc. noaa.gov/mgg/sepm/archive/index.html.

\section{REFERENCES}

Balanyá, J.C., García-Dueñas, V., Azañón, J.M., and Sánchez-Gómez, M., 1998, Alternating contractional and extensional events in the Alpujárride nappes of the Alboran Domain (Betics, Gibraltar Arc): Tectonics, v. 17, p. 977-981.

Cavazza, W., Zuffa, G.G., Camporesi, C., and Ferretti, C., 1993, Sedimentary recycling in a temperate climate drainage basin (Senio River, north-central Italy): composition of source rock, soil profiles, and fluvial deposits, in Johnsson, M.J., and Basu, A., eds., Processes Controlling the Composition of Clastic Sediments: Geological Society of America, Special Paper 284, p. 247-261.

CAzzola, C., and Critelli, S., 1987, Litostratigrafia e petrologia delle quarzoareniti torbiditiche oligomioceniche di Asilah (Catena del Rif, Marocco nordoccidentale): Mineralogica et Petrographica Acta, v. 30, p. 203-226.

Comas, M.C., Zahn, R., Klaus, A., ET AL., 1996, Proceedings of the Ocean Drilling Program, Initial Reports, 161: Mediterranean Basins II: College Station, Texas (Ocean Drilling Program), $1023 \mathrm{p}$.

Critelli, S., AND Ingersoll, R.V., 1994, Sandstone petrology and provenance of the Siwalik Group (northwestern Pakistan and western-southeastern Nepal): Journal of Sedimentary Research, v. A64, p. 815-823.

Critelli, S., and Le Pera, E., 1995, Tectonic evolution of the southern Apennines thrust-belt (Italy) as reflected in modal compositions of Cenozoic sandstone: Journal of Geology, v. 103 , p. $95-105$.

Critelli, S., and Le Pera, E., 1998, Post-Oligocene sediment-dispersal systems and unroofing history of the Calabrian microplate, Italy: International Geology Review, v. 40, p. 609-637. Critelli, S., And Le Pera, E., 2001, Provenance relations and modern sand petrofacies in an uplifted thrust-belt, northern Calabria, Italy, in Valloni, R., and Basu, A., eds., Quantitative Provenance Studies in Italy: Memorie Descrittive della Carta Geologica d'Italia, special issue, in press.

Critelli, S., Le Pera, E., and Ingersoll, R.V., 1997, The effects of source lithology, transport, deposition and sampling scale on the composition of southern California sand: Sedimentology, v. 44, p. 653-671.

DiCKEY, J.S., JR., 1970, Partial fusion products in alpine-type peridotites: Serrania de la Ronda and other examples: Mineralogical Society of America, Special Publication 3, p. 33-49.

Dickinson, W.R., 1985, Interpreting provenance relations from detrital modes of sandstones, in Zuffa, G.G., ed., Provenance of Arenites: North Atlantic Treaty Organization Advanced Study Institute Series 148, Dordrecht, The Netherlands, D. Reidel, p. 333-361.

Dickinson, W.R., 1988, Provenance and sediment dispersal in relation to paleotectonics and 
paleogeography of sedimentary basins, in Kleinsphen, K.L., and Paola, C., eds., New Perspectives in Basin Analysis: New York, Springer-Verlag, p. 3-25.

Dickinson, W.R., Beard, L.S., Brakenridge, G.R., Erjavec, J.L., Ferguson, R.C., Inman, K.F. Knepp, R.A., Lindberg, F.A., And Ryberg, P.T., 1983, Provenance of North American Phanerozoic sandstones in relation to tectonic setting: Geological Society of America, Bulletin, v. 44 , p. $222-235$.

DoRsey, R.J., 1988, Provenance evolution and unroofing history of a modern arc-continen collision: evidence from petrography of Plio-Pleistocene sandstones, eastern Taiwan: Journal of Sedimentary Petrology, v. 58, p. 208-218.

Fallot, P., 1948, Les Cordillères bétiques: Estudios Geológicos, v. 8, p. 83-172.

Garzanti, E., Andò, S., And Scutellà, M., 2000, Actualistic ophiolite provenance: the Cyprus case: Journal of Geology, v. 108, p. 199-218.

Garzanti, E., Scutellà, M., and Vidimari, C., 1998, Provenance from ophiolites and oceanic allochthons: modern beach and river sands from Liguria and the northern Apennines (Italy): Ofioliti, v. 23, p. 65-82.

Guerrera, F., Martín-Algarra, A., and Perrone, V., 1993, Late Oligocene-Miocene syn-/lateorogenic successions in western and central Mediterranean chains from the Betic Cordillera to the southern Apennines: Terra Nova, v. 5, p. 525-544.

Gutierrez-Mas, J.M., Martín-Algarra, A., Domínguez-Bella, S., and Moral-Cardona, J.P., 1991, Introducción a la geología de la Provincia de Cádiz: Universidad de Cádiz, Servicio de Publicaciones, Spain, 315 p.

Ingersoll, R.V., Bullard, T.F., Ford, R.L., Grimm, J.P., Pickle, J.D., and Sares, S.W., 1984 The effect of grain size on detrital modes: a test of the Gazzi-Dickinson point-counting method: Journal of Sedimentary Petrology, v. 54, p. 103-116.

Johnsson, M.J., 1993, The system controlling the composition of clastic sediments, in Johnsson, M.J., and Basu, A., eds., Processes Controlling the Composition of Clastic Sediments: Geological Society of America, Special Paper 284, p. 1-19.

Kairo, S., SutTner, L.J., ANd DutTA, P.K., 1993, Variability in sandstone composition as a function of depositional environment in coarse-grained delta systems, in Johnsson, M.J., and Basu, A., eds., Processes Controlling the Composition of Clastic Sediments: Geological Society of America, Special Paper 284, p. 263-283.

KöPPEN, W., 1901, Versuch einer Klassifikation der klimate vorzugsweise nach ihren Beziehungen zur Pflanzenwelt, Geographische Zeischrift, v. 6, 593 p.

LatTer, K.K., 1998, Provenance of sand within the Alboran Sea [M.S. thesis]: University of Texas at El Paso, El Paso, Texas, 79 p.
Le Pera, E., and Critelli, S., 1997, Sourceland controls on the composition of beach and fluvial sand of the northern Tyrrhenian coast of Calabria, Italy: implications for actualistic petrofacies: Sedimentary Geology, v. 110, p. 81-97.

Le Pera, E., Arribas, J., Critelli, S., and Tortosa, A., 2001, The effects of source rocks and chemical weathering on the petrogenesis of siliciclastic sand from the Neto River (Calabria, Italy): implications for provenance studies: Sedimentology, v. 48, p. 357-378.

LundeEn, M.T., 1978, Emplacement of the Ronda peridotite, Sierra Bermeja, Spain: Geological Society of America, Bulletin, v. 89, p. 172-180.

Marsaglia, K.M., Latter, K.K., And Cline, V., 1999, Sand provenance in the Alboran and Tyrrhenian basins, in Zahn, R., Comas, M.C., and Klaus, A., eds., Proceedings of the Ocean Drilling Program, Scientific Results, 161: Mediterranean Basins II: College Station, Texas (Ocean Drilling Program), p. 37-56.

Odom, I.E., Doe, T.W., And DotT, R.H., 1976, Nature of feldspar-grain size relations in some quartz-rich sandstones: Journal of Sedimentary Petrology, v. 46, p. 862-870.

Schwab, F.L., 1981, Evolution of the western continental margin, French-Italian Alps: sandstone mineralogy as an index of plate tectonic setting: Journal of Geology, v. 89, p. 349 368

SchwAB, F.L., 1986, Sedimentary signatures of foreland basin assemblages: real or counterfeit?, in Allen, P.A., and Homewood, P., eds., Foreland Basins: International Association of Sedimentologists, Special Publication 8, p. 395-410.

VALLONI, R., 1985, Reading provenance from modern marine sands, in Zuffa, G.G., ed., Provenance of Arenites: North Atlantic Treaty Organization Advanced Study Institute Series 148, Dordrecht, The Netherlands, D. Reidel, p. 309-332.

Valloni, R., and Zuffa, G.G., 1984, Provenance changes for arenaceous formations of the northern Apennines, Italy: Geological Society of America, Bulletin, v. 95, p. 1035-1039.

Wejuermars, R., 1991, Geology and tectonics of the Betic Zone, SE Spain: Earth-Science Reviews, v. 31, p. 153-236.

Zahn, R., Comas, M.C., and Klaus, A., Eds., 1999, Proceedings of the Ocean Drilling Program, Scientific Results, 161: Mediterranean Basins II: College Station, Texas (Ocean Drilling Program).

ZuFFA, G.G., 1985, Optical analysis of arenites: influence of methodology on compositional results, in Zuffa, G.G., ed., Provenance of Arenites: North Atlantic Treaty Organization Advanced Study Institute Series 148, Dordrecht, The Netherlands, D. Reidel, p. 165-189.

Received 2 October 2001; accepted 10 July 2002. 